\title{
THE UNITED STATES AND INTERNATIONAL STRAITS: TWO CASES FROM THE $19^{\mathrm{TH}}$ CENTURY
}

\author{
Elif YENEROĞLU* - Onur KINLI**
}

\begin{abstract}
$\ddot{O} z$
Amerika Birleşik Devletleri ve Uluslararası Boğazlar: 19. Yüzyıldan İki Vaka

Deniz hukukunda açık denizlerin serbestliği ilkesi en çok tartışılan ilkelerden biridir. Uluslararası suları birbirine bağlayan boğazlar da kaçınılmaz olarak bu tartışmanın bir parçası haline gelmiştir. Avrupa'nın uluslararası hukukun gelişimi üzerindeki belirleyici etkisi kıta dışı aktörlerin, özellikle de Amerika Birleşik Devletleri'nin yükselişiyle birlikte 19. bir meydan okumayla karşılaşmıştır. Amerika Birleşik Devletleri, bağımsızlığını kazandığı tarihten itibaren açık denizlerin serbestliği ilkesinin istikrarlı savunucularından biri olmuştur. Buna paralel olarak uluslararası boğazlardan geçişi düzenleyen uygulamalar da özellikle 19. yüzyılın ikinci çeyreğinden itibaren ABD'nin üzerinde durduğu konulardan biri olmuş, denizlerin serbestliği ilkesini ihlal ettiğini düşündüğü uygulamaları bertaraf etmeye yönelik politikalar izlemiştir. Bu çerçevede makale ABD'nin boğazlardan geçiş rejimine karşı uyguladığı politikayı iki örnek üzerinden incelemeyi hedeflemektedir. Danimarka Sound ve Türk/Osmanlı Boğazları'nı ele alan çalışma, ABD'nin yerleşik uygulamalara meydan okuma konusunda neden farklı politikaları tercih ettiğini incelemektedir.
\end{abstract}

Anahtar kelimeler: Danimarka Sound, Türk Boğazları, Uluslararası Boğazlar, Deniz hukuku, Amerikan Dış Politikası

Abstract

Freedom of the seas is one of the most debated principles of the law of the sea. International straits which connect international waters constitute an inevitable part of this debate. The impact of Europe on the development of international law began to be challenged in the $19^{\text {th }}$ century with the rise of non-European actors. The United States has been a consistent supporter of this principle since its inception as an independent state. Since the first quarter of the $19^{\text {th }}$ century rules and regulations governing navigation through international straits has been a specific case of interest for the US. In

\footnotetext{
* Assoc. Prof., Ege University, Faculty of Economics and Administrative Sciences, Department of International Relations, Izmir/Turkey.

E-mail: elif.yeneroglu.kutbay@ ege.edu.tr. ORCID: 0000-0002-7432-2323

** Asst. Prof., Ege University, Faculty of Economics and Administrative Sciences, Department of International Relations, Izmir/Turkey.

E-mail: onur.kinli@ege.edu.tr. ORCID: 0000-0002-4823-1508

(Makale Gönderim Tarihi: 22.06.2021 - Makale Kabul Tarihi: 14.12.2021)
} 


\section{Elif YENEROĞLU - Onur KINLI}

line with this policy the US pursued policies that would abandon practices violating the principle of freedom of the seas. Within this framework this article examines the US policy on international straits through two cases. The article takes the cases of the Danish Sound and Turkish Straits and explores the reasons why it preferred different policies in these cases.

Keywords: Danish Sound, Turkish Straits, International Straits, Law of the Sea, American Foreign Policy

\section{Introduction}

One of the dilemmas of the law of the sea is to seek a balance between nations that claim sovereignty over bodies of water which they deem vital to their interests and those that see such attempts as restrictions upon navigational freedoms. Passage through international straits forms an indispensable part of this dilemma. Irreconcilable approaches on this issue often led to controversies and even wars. As a nation born out of the clash of commercial interests the United States was a consistent supporter of freedom of the seas hence in favor of removing any restrictions imposed upon the implementation of this principle. Initially much of the American interests regarding freedom of the seas centered around ensuring the protection of neutral trade during war. ${ }^{1}$ It is no surprise that the assault on American trade during Napoleonic wars was among the major reasons why the US declared war against Britain in 1812. As American commercial interests expanded in the 1830s and 1840s its interest in freedom of the seas also expanded to cover all aspects of the matter including controversies relating to navigational freedoms in the straits.

In this respect we see two simultaneous attempts by the US in mid- $19^{\text {th }}$ century to remove restrictions on straits imposed by coastal states: Danish Sound dues and restrictions on passage of war vessels through Turkish Straits. While the US was instrumental in the abolition of the Sound dues it did not demonstrate the same perseverance to reverse the status quo in the Turkish Straits. It is the purpose of this paper to analyze the US policy regarding these two cases and to explore the reasons why it preferred to adopt a persistent policy on the former and a rather detached and cautious policy on the latter.

The study is divided into three sections. The first section will give a brief introduction on the development of general rules on passage through international straits. The second section will focus on the cases giving a historical background, general policies of the interested parties with specific emphasis on the US policy and the final resolution of the issue. The conclusion will compare and contrast the two cases in terms of the US policy. The study argues that in the final analysis the fundamental factors shaping US policy are not consistency and perseverance but vital interests, which in this case can be argued as the policy of non-intervention or avoid creating situations that would require the US to meddle with the intricate politics of the European States System. This policy was shaped by the Monroe Doctrine, which is erroneously defined as isolationist in international relations.

It is often misleading when we simplify a case in terms of dealing with certain

\footnotetext{
${ }^{1}$ For the discussion the history of American policy on freedom of the seas see, Hays 1918; Hirst 1918; Cecil and Forster 1929.
} 
practices of International Law and foreign policy of a certain state. By thoroughly analyzing historical processes the study aims demonstrate the mutual interaction between foreign policies of states and the development of the rules of international law. For the Danish Sound for example, contemporary international law books, while attribute importance to the case in terms of the development of international law regarding passage through straits, they tend to overlook the international dynamics that surrounded it. Because the Turkish Straits are categorized under international straits with special regimes much space is spared for their status albeit without giving the background which led to that special status. ${ }^{2}$ As for American foreign policy we can identify two distinct periods in terms of attention given to these two cases: the $19^{\text {th }}$ century and early $20^{\text {th }}$ century sources that deal with American foreign policy tend to give more emphasis on the Danish Sound case because the US had the leading role in the abolition of the dues. The case of Turkish Straits is mostly taken as an example of a special regime not by American foreign policy scholars but by American international law scholars within the framework of navigational freedoms. ${ }^{3}$ Following the Second World War, the focus shifted towards super-power rivalry in the Cold War and while Danish Sound attracted no attention the status of the Turkish Straits concerned the US not from the perspective of freedom of the seas but as a barrier to Soviet naval expansion in the Mediterranean. Thus, the Montreux Convention (1936) which limited the passage of both the riparian and nonriparian war vessels became a convenient tool for containing the Soviet Union. ${ }^{4}$

International law books, primary sources gathered from the Foreign Relations of the United States online archives, statistical registers, collection of private letters and other works by prominent figures of American foreign policy are the primary sources of the study. Secondary sources such as articles and books are also used in order to have a comprehensive understanding of the subject.

\section{General Rules of Navigation in International Straits in the $19^{\text {th }}$ Century}

Attempts to establish a separate legal regime for international straits began only towards the end of the $19^{\text {th }}$ century. ${ }^{5}$ It took yet another century to realize that goal. ${ }^{6}$ Until then passage through straits was dealt with as a part of the issues relating to the territorial

\footnotetext{
${ }^{2}$ See for example, Bing Bing Jia, The regime of Straits in International Law, Oxford, Clarendon Press, 1998 and Nihan Ünlü, The Legal Regime of the Turkish Straits, The Hague, Martinus Nijhoff Publishers, 2002. ${ }^{3}$ Moore 1906 and 1908; and Wheaton 1842 and Woolsey 1860 are examples.

${ }^{4}$ Hastedt's Encyclopedia of American Foreign Policy for example contains no entries with regards to the Danish Sound issue.

${ }^{5}$ In 1894 Institut Droit De International formulated basic rules and Godey was one of the first jurists who argued that although straits may form a part of the territorial sea, they should be subject to a special regime. Mohd Rusli 2012, p. 111.

${ }^{6}$ Until the Corfu Channel Case (1949) legal criteria about what constituted an international strait was not laid down. The legal regime for straits was established much later, in 1982 with the United Nations Convention on the Law of the Sea. It is worth mentioning that the Convention recognizes the the legal regime in straits in which passage is regulated in whole or in part by long-standing international conventions in force specifically relating to such straits (article 35 (c)).
} 


\section{Elif YENEROĞLU - Onur KINLI}

sea. ${ }^{7}$ However, this did not mean that a customary law had not evolved out of the practice of nations neither did it mean that jurists did not have any interest on the issue. As international trade thrived in the $15^{\text {th }}$ century so did debate whether states could exercise sovereignty over high seas as claimed by the Spanish and the Portuguese. Although renowned as the champion for the principle of freedom of the seas Grotius recognized that there existed parts of the sea on which a state is entitled to exercise sovereignty, namely gulfs, straits, and coasts that are adjacent to the coast later to be called as the "territorial sea." ${ }^{8}$ However, he opined that the sovereignty exercised could not go as far as to prevent foreign vessels using these parts of the sea in a peaceful manner, hence innocent passage. Grotius was also of the opinion that a state could charge moderate tolls to defray the costs of maintaining the safety of traffic in addition to military expenses for the purpose of defending its own territory from attacks by foreign navies or pirates. What constituted moderate, however, was highly debatable. One thing was clear though, that states should not levy tolls merely for passage, for this would be against the notion of innocent passage. ${ }^{9}$ It was the German jurist Pufendorf who was the first to take a special interest on straits probably because he came into contact with the political and legal problems of the Baltic straits as an adviser to the Swedish diplomat Coyet, who after the peace of Roskilde in 1648 started negotiations in Copenhagen. ${ }^{10}$ While specifically arguing that states can control parts of straits close to their coasts he follows Grotius' line of thinking on the issue of tolls. Vattel in the $18^{\text {th }}$ century was the first to make a distinction between straits used for international navigation and those that do not have such a function. As long as the passage was innocent, he argued, the states had no right to restrict or deny passage through straits. He was also in favor of levying tolls as long as they served the purpose of defraying the costs mentioned above.

With the $19^{\text {th }}$ century a more liberal approach to the issue of passage through straits began to be adopted. Martín argues that this change of orientation was related to the emancipation of the Spanish colonies in America, which involved the consolidation of the 'open doors policy' for trade between Europe and America, with an evident repercussion on the conception of the regime regulating the passage through the straits. ${ }^{11}$ Martín's argument may explain in part why the US began to pursue a more rigorous policy towards removing any restrictions that might hinder passage through straits. Therefore, during the $19^{\text {th }}$ century, while the distinction made by Vattel came to be practiced more, the restrictions on passage through the straits began to be questioned more frequently. It was, however, generally recognized that in narrow straits, where the coastal state is sovereign on both sides of a strait, certain restrictions to maintain its security could be imposed. This liberal orientation, however, was bound to clash with the policies of coastal states which were perfectly aware of the strategic and economic advantages that the straits

\footnotetext{
${ }^{7}$ By the $19^{\text {th }}$ century it was a generally accepted rule that the width of the territorial sea is three miles, that is, the range of a cannon shot.

${ }^{8}$ Martín 2008, p. 2.

${ }^{9}$ Caminos and Cogliati-Bantz 2014, p. 359.

${ }^{10}$ Eduard. 2002, p. 13.

${ }^{11}$ Martín, 2008, p. 3.
} 
provided and, attempt[ed] to manipulate the right to navigate international straits as a source of wealth or a means of achieving particular political objectives. ${ }^{12}$ The cases that this paper deals with are in line with this argument.

\section{The US and the Abolition of the Sound Dues}

American books written on international law and American diplomacy in the late $19^{\text {th }}$ and early $20^{\text {th }}$ century give particular emphasis to the issue of the Sound dues because it was one of the rare European cases in which the US played a central role. It did not, however, join the final treaty which was concluded between the major powers of Europe but rather preferred to sign a separate treaty for settling the matter with Denmark.

The Baltic and the North Seas are connected through three waterways all of which include Danish territories. From west to east these are the Little Belt, the Great Belt and the Sound. Historically the Sound had been the shortest and most suitable passage to the Baltic and Danish kings tended to divert maritime traffic to the Sound, but as maritime technology improved the Great Belt is more preferred by larger vessels today. Together with the Kiel Canal the Sound is still preferred for vessels of smaller tonnage hence still the busiest passage today. ${ }^{13}$ The narrowest point of the Sound is 4 kilometers, between Helsingor (Denmark) and Helsinborg (Sweden), which makes it an effective control point strategically.

Until 1658, both shores of the Sound were Danish territory. ${ }^{14}$ Beginning with the $16^{\text {th }}$ century the growing interest of northern European powers on the Baltic trade ${ }^{15}$ gave the Danish kings an unprecedented strategic and economic advantage which enabled Denmark to become a regional power in northern Europe. At this point it is necessary to give brief information on the political structure of Denmark because this will help us to explain the importance of the Sound dues for Danish kings. In 1397 the three Nordic kingdoms (Denmark, Norway and Sweden) established the Kalmar Union against the commercial domination of Hanse towns in the region. What started as mere a union of crowns than governments ${ }^{16}$ ended up in Danish hegemony over Norway and Sweden which caused much resentment among the other two kingdoms and hence led to a number of uprisings particularly in Sweden. These struggles resulted in Swedish independence in 1523 followed by Norway's fusion to Denmark in 1536. Apart from the territories of Denmark and Norway the Danish kings, through their possession of the Duchies of Schleswig and Holstein were also the princes of the Habsburg Empire. ${ }^{17}$ Until the establishment of an absolute monarchy in 1660 the power struggles more or less reflected

\footnotetext{
${ }^{12}$ Burke et. al. 1983, p. 401.

${ }^{13}$ Alexandersson 1982, p. 63.

${ }^{14}$ See footnote 28 .

${ }^{15}$ A few figures would suffice to demonstrate the dramatic increase in the volume of trade in the Baltic. In 1497 the total number of ships that passed through the Sound was 800. In 1537 the number rose to 1897 and at the end of the $16^{\text {th }}$ century the number of ships passing through the Sound was approximately 5400 annually. Lockhart 2007, p. 88.

${ }^{16}$ Bellamy 1997, p. 63; Etting 2004, pp. 96-103.

${ }^{17}$ Lockhart 2007, p. 3.
} 


\section{Elif YENEROĞLU - Onur KINLI}

typical feudal politics in Denmark. The king was elected by a Council (Rigsråd) including landed aristocracy and the clergy. Before accession to throne, the elected kings of Denmark were to, sign a håndfæstning (accession charter) in which [they] agreed to abide by the decisions of the Rigsråd, to ensure that the number of members within it were maintained at a required level, and that certain positions in the central administration were filled. ${ }^{18}$ The fact that the king chose the members of the Council may seem problematic, but most of the time the composition of the Council represented a political balance because of the mere fact that the king needed the Council to rule the state. A powerful Council, with an accession charter that limited the powers of the king could, therefore, exert considerable authority over the administration of the state. ${ }^{19}$

Whenever the kings of Denmark fought wars that the Council did not give its approval to, they increased the dues to finance their wars, which in turn caused resentment among the powers that benefitted from the lucrative Baltic trade. It should also be mentioned that the dues allowed the kings of Denmark to finance a powerful navy not for the sole purpose of exercising control over Baltic trade but also as an instrument of their power in domestic politics. Hence, the [dues] and the navy were interconnected instruments of centralization and state building which made the Danish kings more powerful than most European rulers of territories with strong aristocracies. ${ }^{20}$ On the other hand, one should also keep in mind that while a strongly centralized state was established by 1660 , Denmark's position as a regional power was challenged first by Sweden and then Russia which was in the process of becoming a dominant power in the Baltic in the early $18^{\text {th }}$ century. A non-Baltic power, Britain began to exercise considerable influence over the political and commercial affairs of the Baltic as well. It is within this context that the domestic and international significance of Sound dues should be examined. Numerous examples from the $15^{\text {th }}$ to the $17^{\text {th }}$ centuries demonstrate how Denmark effectively exploited its strategic advantage over the Sound both politically and commercially. ${ }^{21}$

Major turning points in the history of the Sound dues will reveal the legal basis of the claims made by various parties for the abolition of them. As early as $14^{\text {th }}$ century Sound dues ${ }^{22}$ began to come up as an issue between Denmark and the Hanseatic League, the dominant commercial power in the Baltic, but back then they did not have a distinct character for two reasons: First, the Danes did not possess both shores of the Sound so as to claim exclusive sovereignty over passage of vessels, and second the quarrels between the Hanse towns and Denmark in the Sound region were about taxation of commerce and fisheries rather than the terms of passage through the Sound..$^{23}$ The dues to be paid for

\footnotetext{
${ }^{18}$ Bellamy 1997, p. 56.

${ }^{19}$ Bellamy 1997, p. 57.

${ }^{20}$ Glete 2002, p. 115.

${ }^{21}$ Glete (pp. 112-130) and Lockhart provide a full accounts of events on this subject.

22 Dues were also levied on the Little and Great Belts but since the traffic through them was much less compared to the Sound, when we talk about Sound dues, we also cover the dues levied on the Little and Great Belts.

${ }^{23}$ Menefee 1996, p. 101.
} 
transit in particular dates back to the $15^{\text {th }}$ century. The vessels were to be stopped at Elsinore and pay a certain amount for the ship, the cargo, lighthouse services, expenses, commissions and etc. ${ }^{24}$ Although Denmark took the necessary measures for the protection of commerce against pirates and other enemies, and guaranteed safe passage through the Sound by maintaining lighthouses and buoys, the dues were rather claimed as a sovereign right than payment in return for these services. This is best demonstrated in the reply given to the objections of the Hanseatic league that navigation through the Sound should be free. King Erik of Denmark argued that kings and princes elsewhere in Europe laid down similar dues and that he regarded the Sound as a river flowing through his territory. ${ }^{25}$ At a time when the notion of modern state was nascent and the lands ruled by kings were seen as their own possessions King Erik's claim was not that peculiar. On various occasions the claim to sovereignty went as far as to confiscate cargo to provide for the needs of the king or to impress foreign sailors to service. ${ }^{26}$

Hessenland argued that it was the Dutch that introduced the Sound dues into the politics and law of nations as an obligation when they signed the Treaty of Spire in $1544 .{ }^{27}$ Apart from the peril of accepting an ancient tradition as legally binding, disputes arose between the Dutch and the Danish kings later on because of the wording in the treaty. While the Dutch argued that the dues did not cover the cargo but only the dues to be paid for the ship itself the Danish kings interpreted the treaty in a very liberal manner arguing that the Dutch recognized the king's right to levy taxes as an indication of his legitimate sovereignty. ${ }^{28}$ As the dues served to finance political objectives, throughout the course of the $16^{\text {th }}$ and $17^{\text {th }}$ centuries Danish kings resorted to arbitrary increases and frequently broke off treaties ${ }^{29}$ which in turn led to various combinations of alliances between the Netherlands, the Hanseatic League, and Sweden against Denmark for the protection of their commerce in the Baltic Sea. ${ }^{30}$ Temporary exemptions from the dues were attained from time to time by individual states, but an overall abandonment of the dues was not realized.

The rivalry between Sweden and Denmark played a crucial role in the history of the Sound dues. In 1645 Sweden obtained exemption from the duties by the Treaty of Bromesbro. ${ }^{31}$ In 1658 Denmark lost Scania (the eastern side of the Sound) to Sweden. The hostilities, however, continued until 1660 when the French, the English and the Dutch intervened to broker a peace deal with the apparent aim of striking a balance between Denmark and Sweden so that neither could exert absolute control over the Sound. With the

\footnotetext{
${ }^{24}$ Wheaton 1842, p.159.

${ }^{25}$ Menefee 1996, pp. 101-02.

${ }^{26}$ Menefee 1996, p. 107.

${ }^{27}$ Hessenland 1855, p. 406.

${ }^{28}$ Menefee 1996, p. 105.

${ }^{29}$ The Dutch for example paid a substantial amount for the purchase of the right of exemption from the Sound dues in 1649. Three years later the Danish king began demanding the dues again.

${ }^{30}$ Wheaton 1842, p. 159.

${ }^{31}$ Woolsey 1860, p. 128. In 1658 Denmark lost Scania (the eastern side of the Sound) to Sweden and with a treaty signed in 1660 agreed to pay a small portion of Sound dues collected at Elsinore to Sweden in return for renunciation of the latter of any claim to the Sound dues.
} 


\section{Elif YENEROĞLU - Onur KINLI}

treaty of 1660 Denmark recognized the loss of Scania but was able to hold on to its "ancient right" to collect dues from the Sound. Denmark was to pay a small portion of the revenue collected from the Sound to Sweden in return for renunciation by the latter of any claim to the dues. Therefore, the argument that the Sound was a river that flowed within the king's domain and that the king was entitled to collect dues should have ceased with the loss of Scania, but they continued to be collected without much protest from other nations.

The milestone in the history of the Sound dues, however, was not the rivalry between Sweden and Denmark and the resulting status quo in $1660,{ }^{32}$ but the Treaty of Christianople concluded in 1645 with the Dutch. This treaty determined the number of dues to be levied on the Dutch vessels and cargoes. A tariff of specific duties on certain articles was annexed to the treaty, and it was stipulated that goods not mentioned in the list should pay according to mercantile usage and what has been practiced from ancient times. ${ }^{33}$ In 1701, another treaty was signed with the Dutch in Copenhagen, which solved the problem of non-specified articles in the previous one. The new treaty stipulated that, the goods not specified in the former treaty are to be paid according to their value (ad valorem), that is, they are to be valued according to the places from whence they come, and one per centum of their value to be paid. ${ }^{34}$

These two treaties became a reference point for subsequent treaties that Denmark signed with other states and established the dual standard of "privileged" and "nonprivileged" states. The privileged states were those which concluded commercial treaties with Denmark, often including most-favored-nation clause, and they were to pay the dues specified in the 1645 tariff. The so-called non-privileged states, those that did not conclude any commercial treaties with Denmark continued to pay different rates. On the other hand, since the changes in the value of commodities and the progress of commerce were unforeseen, by the gradual decrease of prices, duties on some articles reached a level as high seven percent. The determination of rates on articles not enumerated in the treaties was often left at the mercy of the officials charged with the computation, thus creating an arbitrary valuation. ${ }^{35}$ Wheaton in 1842 argued that the 1645 and 1701 treaties formed the conventional law respecting the Sound duties. ${ }^{36}$ Halleck, writing in 1861 , that is, after the abolition of the Sound dues, argued that nations either paid or refused to pay such duties, but the claim itself has never been sanctioned by general acquiescence. ${ }^{37}$ Nevertheless, the two treaties seemed to put an end to disputes over the Sound dues and therefore established a general acquiescence at least for more than a century no matter how unjust they seemed to other nations.

From 1816 onwards the revenue collected from the dues were transferred to public treasury. This may have provided yet again another opportunity for other nations to

\footnotetext{
${ }^{32}$ Sweden's exemption from the Sound dues ended in 1721, when they suffered a serious blow to their power.

${ }^{33}$ Wheaton 1842 , p. 160.

${ }^{34}$ Wheaton 1842 , p. 160.

${ }^{35}$ Hessenland 1855, p. 51.

${ }^{36}$ Wheaton 1842, p. 161.

${ }^{37}$ Halleck 1861. P. 133.
} 
challenge the collection of dues, but no action was taken. This was probably due to the damage that Denmark suffered during the Napoleonic wars, and the cession of Norway to Sweden further exacerbated the economic situation in the country. ${ }^{38}$ It is therefore argued that although the Congress of Vienna adopted the principle of free navigation in rivers and seas the Sound was excluded from this sphere to let Denmark continue to collect dues as a compensation to cover its losses. In the first half of the $19^{\text {th }}$ century, the ships passing through the Sound reached an average of 10,000 per year and only a small portion of the revenue collected from the dues was used to finance the costs of maintenance. The Sound dues sometimes constituted as high as ten percent of the national income of Denmark. ${ }^{39}$ In the $19^{\text {th }}$ century, therefore, it was the central government and not the king that became dependent on the revenue collected from the Sound. The fact that the Sound dues were pledged as a security on a loan in 1825 and during the war with Prussia (1848-50) made Denmark more dependent on and hence more reluctant to abolish the dues, at least without any compensation. ${ }^{40}$ The final revision on dues took place in 1841 when upon the complaints of the British merchants the British government concluded a new treaty with Denmark whereby the rates of 100 articles out of 500 were revised. The initiative to renew the rates did not come from the British government itself but was rather the result of complaints of a group of merchants from the port of Hull, the main trade of which was carried with the Baltic, Scandinavia and the Low Countries. The merchants' efforts were directed at abolishing the Sound dues altogether, but the government, reluctant to put a burden on the taxpayers, sufficed it to conduct negotiations which would only lead to a revision of rates on certain products. ${ }^{41}$

The US became acquainted with the dues in 1784, when the Danish Board of Customs ordered that vessels that passed the Sound had to be treated in a "non-privileged" way. ${ }^{42}$ The main trading partner of the US in the Baltic was Russia. About 90 percent of Russo-American trade was carried out through the Sound and almost entirely on American ships. In the 1820 s the main article of American export to Russia was sugar, which was to be replaced by cotton and cotton wool in the 1850s. Between 1783-1860 the American ships that sailed to the Baltic was $9500 .{ }^{43}$

As early as 1826 the legal validity of the Sound dues was being questioned by the Americans. In an article that was published in Boston Magazine and reprinted in the North American Review the dues are compared to the tribute that the Barbary States demanded and were only to be gotten rid of by American armed action. The author of the article asked whether there is now an adequate existing reason by which, according to the eternal and unchanging principles of natural justice, we, as an independent nation, are

\footnotetext{
${ }^{38}$ Moore 1906, p. 662.

${ }^{39}$ Jacob 1921, p. 101.

${ }^{40}$ Jacob 1921, p. 101. Rothschild was one of the financiers of Danish loans and perhaps this is one reason why Britain, despite constant protests from its merchants, did not take any serious action to abolish the Sound dues.

${ }^{41}$ Hansard's Parliamentary Debates, vol. LVII, 1841, pp. 294-306.

${ }^{42}$ Ahonen, 2005, p. 107.

${ }^{43}$ Ahonen 2005, p. i (Abstract).
} 


\section{Elif YENEROĞLU - Onur KINLI}

bound to accede to the demand. ${ }^{44} 1826$ is also the year when a treaty of Friendship, Commerce and Navigation was concluded between the two countries which placed the US among the "privileged" nations by virtue of article five: neither the vessels of the US nor their cargoes shall, when they pass the Sound or the Belts, pay higher or other duties than those which are or may be paid by the most favored nation. The US was now among the "privileged" nations enjoying lower dues, which also meant that it acquiesced to the right of Denmark on the collection of dues. The dissenting voices against the payment of dues were silenced for a while with the signing of the treaty of commerce.

The US took the initial step for the abolition of the Sound dues in early 1840s. Kirchner argues that the debate was probably raised rather artificially in 1841 and that the government was compelled to take action to calm down the agitators. ${ }^{45}$ There was, however, a logic behind such agitation on the part of the American merchants: As mentioned earlier the treaty of 1841 between Denmark and Britain determined new rates, which in fact automatically applied to the US as well because of the most-favored-nation clause embedded in the treaty of 1826 . However, some American merchants considered the new arrangement unfavorable because the duty on raw cotton, a major American export product to Russia was $6 \%$ per hundred pounds, while the duty on cotton twist, mainly produced by Britain was only $2 \%$. In 1846, upon the pressure put by American diplomats the duty on raw cotton was finally reduced to approximately to the same level as cotton twist. ${ }^{46}$ One other reason was the complaints of a number of American merchants that they were paying more dues than other nations' ships. This argument needs clarification: while the trip to the Baltic was hardly more than a coasting voyage for British or Continental vessels, the American vessels were obliged to cross the Atlantic and were therefore larger in size and carried more cargo than those of British or Continental states. Thus, although the number of American vessels that stopped at Elsinore to pay the dues were much less in number (approximately 100 ships per year) the amount paid by one American vessel was greater than other British or Continental vessels. We should also take into consideration two other factors: the total amount of annual dues paid by American vessels hardly exceeded $2 \%$ of the total dues paid by all the states. Britain and Russia for instance, each paid almost $30 \%$ of the total dues in any given year. Furthermore, when calculated it turned out that in 1843 for example the Americans paid a duty of only $\$ 5$ per ton. In addition to that, the general complaint of American merchants was not the Sound dues but the time they lost while waiting in Elsinore for the dues to be collected and Russian import dues which sometimes reached a level as high as $35 \%$. These factors might have been instrumental in taking up the Sound dues question, but we should also take into consideration the growing tendency towards free trade. As the number of US ships entering the Baltic increased, the objection to the Sound dues became more heard from merchants. ${ }^{47}$ Parallel to the dramatic increase in the

\footnotetext{
44 "The Claims of the Citizens of the United States on Denmark Examined" The North American Review, vol. XXII (new series vol. XIII), 1826 (Boston), pp. 458-59.

${ }^{45}$ Kirchner 1975, p. 102.

${ }^{46}$ Ahonen 2005, p. 111.

${ }^{47}$ Kirchner 1975, pp. 102-03.
} 
manufacturing output, the 1840s saw the worldwide expansion of American commercial interests. ${ }^{48}$ The principle of freedom of the seas, on which the US gave emphasis to neutral trade during war was expanding its scope to cover any issue that would hinder free flow of goods.

Secretary of State Daniel Webster, who was known to be an advocate of free trade and free shipping, first raised the Sound dues question in 1841 on the principle of freedom of the seas. ${ }^{49}$ Although he questioned the right of Denmark to levy dues he also admitted that by the treaty of 1826, the US had not denied them. His suggestion was to enter into friendly relations with [Denmark], with a view to securing the commerce of the United States, a full participation in any reduction of these duties, or the benefits resulting from any new arrangements respecting them which may be granted to the commerce of other States. ${ }^{50}$ His successor Abel P. Upshur took a harder stance in 1843 and claimed that Denmark had no right under natural or public law to demand such dues. He suggested that, the time has arrived when the US may properly take some decisive steps to relieve its Baltic trade from oppression. ${ }^{51}$ The untimely death of Secretary Upshur, the annexation of Texas (1845) and war with Mexico (1846-48) prevented the American government from pursuing the matter rigorously.

In 1848, Robert Flenniken, the new minister to Denmark brought up the question of the Sound dues in a conversation with the Danish Minister of Foreign Affairs. Flenniken wrote to Buchanan that the Danish minister could not defend the principle upon which these dues are exacted. ${ }^{52}$ The first formal attempt for the abolition of the dues was made in the same year. The US based its claims on the principle of the freedom of the seas which required under the law of nations that the navigation of the two seas connected by this strait is free to all nations; and therefore the navigation of the channel by which they are connected ought also to be free.$^{53}$ Although the Danish foreign minister formerly acknowledged the peculiarity of collecting dues the formal stance of the government was that the dues had immemorial prescription and that this right was also acknowledged by treaties with other states. ${ }^{54}$ In response, the US argued that the dues were applied in a remote and barbarous age, even before the discovery of America and therefore the US could not be forced to pay for them and that they applied strictly to the European states. ${ }^{55}$ The fifth article of the 1826 treaty with Denmark, where the US acquiesced to the right of Denmark for collecting such duties weakened the US arguments. However, Moore argued that the article did not induce the US to pay the dues forever because the treaty

\footnotetext{
${ }^{48}$ In the 1820 s, cotton textile production increased by almost 80 percent, the production of pig iron by more than 50 percent, and the production of railroad iron almost doubled in the US. Ahonen 2005 , p. 44.

${ }^{49}$ Ahonen 2005, pp. 114-115.

50 "Sound Dues-Germanic Powers", Department of State, 1841, published in Hazard's United States Commercial and Statistical Register, vol. IV, no. 25, 1841, pp. 397-398.

${ }^{51}$ McDermott 1855, p. 20.

${ }_{52}$ Moore (ed.) 1908, p. 220.

${ }^{53}$ Moore 1908, p. 220.

${ }^{54}$ Woolsey 1860, p. 128.

${ }^{55}$ Moore 1906, p. 660.
} 


\section{Elif YENEROĞLU - Onur KINLI}

was signed for a period of ten years. With the termination of the treaty the US could not be held liable for paying the dues. ${ }^{56}$ Indeed, this was the course taken by the US. In a letter to Flenniken, Buchanan complained that the US had to pay a large tax ... for liberty to pass through a strait between two seas, which, by the law of nature and of nations, is free and open to all mankind ${ }^{57}$ and that the US would no longer submit to this exaction. The US Government was ready to terminate the treaty of 1826 should Denmark insist on collecting the dues. Thus, he ordered Mr. Flenniken to open a discussion with the Danish Ministry of Foreign Affairs. The US, on the other hand, was trying to find a middle ground for the abolition of the dues because the instructions to Flenniken covered payment of $\$ 250,000$ not for the purchase of a right enjoyed by Denmark, but as an equitable equivalent for that branch of her revenue which she would thus give up. ${ }^{58}$ This was in fact a thinly disguised offer ${ }^{59}$ to purchase the right of Denmark to levy dues which the US claimed it had no right to do so. However, Denmark was engaged in a war over the Duchies of Schleswig and Holstein with Prussia, the power most opposed to the Sound Dues. Perhaps, Buchanan thought that the war between Denmark and Prussia would bring up the question of dues and then it would be the right time to intervene on behalf of the US. Upon the request of the Danish Government, however, the US agreed to postpone the issue. Although Prussia pulled out of the war in the middle of 1849, the fighting with other German states and Schleswig continued until the Concert of Europe reached a final solution in 1852 .

No further steps were taken until 1854 when the new Secretary of State William Marcy instructed Henry Bedinger, the new minister to Denmark to reach a conclusion on the Sound dues with the remark that the US can recognize no immemorial usage as obligatory, when it conflicts with natural privileges and international law. ${ }^{60}$ Contrary to the previous position Marcy also instructed Bedinger that the US would not make any payments or give any commercial privileges in return for the abolition of the dues. The timing of such a move was, however, could not be worse because now the Crimean War was in full swing, threatening to disrupt the European concert. This time the request of the Danish government to postpone the issue to the end of the war was declined because the ten-year period of the commercial treaty with Denmark was to terminate in 1856. Therefore, the US deemed it necessary to solve the matter in due time. In his annual message (1854) President Pierce advised the Congress to terminate the 1826 treaty with Denmark. ${ }^{61}$ The previous attempts by the US regarding the abolition of the dues were met with resistance both by Britain and Russia, but since these states were at war against each other the US might have seen a window of opportunity to push forward with the process. ${ }^{62}$

\footnotetext{
${ }^{56}$ Moore 1906, p. 661.

${ }^{57}$ Moore 1908, p. 221.

${ }^{58}$ Hessenland, 1855, p. 59.

${ }^{59}$ Hessenland, 1855, p. 59.

${ }^{60}$ Hessenland, 1855, p. 59.

61 Second Annual Message of Franklin Pierce, December 03, 1854, https://www.presidency.ucsb.edu/documents/second-annual-message-8 Accessed November 18, 2019.

${ }^{62}$ Ahonen pp. 115-116.
} 
Denmark was, however, in no position to accept the abolition of the dues for a single state. The most-favored-nations clauses embedded in Denmark's commercial treaties with other nations meant that as soon as the government accepted the US position the dues would be abolished for other states without giving Denmark any chance of remuneration. On the other hand, the US had already announced the termination of the treaty of 1826, which implied that American ships would sail through the Sound without paying the dues thereby setting a precedent for other nations' ships. With no room to maneuver the Danish government had to yield to the pressure, but if the dues were to be abolished it was to be done in a proper way: through negotiation and compensation.

In October 1855 Denmark sent a note to the interested parties for the meeting of a congress to discuss the Sound dues. The note stated that the time was unfavorable for a settlement of the question, but on account of the action taken by the US, it was necessary for the powers to come to some agreement on the subject. ${ }^{63}$ The Congress convened in two major sessions, in January and February 1856 attended by the representatives of Austria, Belgium, France, Britain, Holland, Oldenburg, Prussia, Russia, Spain and Sweden. Denmark demanded a total of 35,000,000 rix-dollars to be divided among the nations according to their frequency of use. Except a short hesitation on the part of Britain, the participants, which later joined by representatives from Hannover, Mecklenburg and the Hansa Towns, were in favor of the permanent abolition of the dues in the manner that Denmark suggested. Rather than concluding separate treaties with Denmark, in harmony with the idea of the Concert of Europe, a general treaty was signed on March 14, 1857 that abolished the dues and established the redemption and payments. ${ }^{64}$

Although the whole process of abolishing the Sound dues was initiated by the US it did not attend the Congress. In his annual message (December 1855) President Pierce explained the reasons why he declined the invitation of Denmark: first, Denmark stated that the matter would be treated not as a commercial or money transaction, but as a political matter. Implicit in this comment was Denmark's rejection to question its sovereign rights to levy dues. Pierce argued that if the convention were allowed to take cognizance of that particular question still it would not be competent to deal with the great international principle involved which affects the right in other cases of navigation and commercial freedom, as well as that of access to the Baltic. ${ }^{65}$ Therefore, the US was objecting not to the amount of dues but to the fact that they did not have any place in international law. Recognizing such a right meant that Denmark treated the Baltic as a closed sea and could obstruct the passage, and allow only those who pay tribute to it. More important than that the history of the Sound dues showed that it was a highly politicized matter, intermingled with the balance of power in Europe and this was the very thing that the US had a fixed determination to avoid being brought within its vortex. ${ }^{66}$

\footnotetext{
${ }^{63}$ Soren, p. 111.

${ }^{64}$ Jacob 1921, p. 117.

${ }^{65}$ Richardson, 1897 , p. 335.

${ }^{66}$ From Marcy to Bedinger, November 3, 1855, in Message from the President to the Two Houses of Congress at the Commencement of the First Session of the $34^{\text {th }}$ Congress, part I, Printed by Beverly Tucker, 1855, p. 40.
} 


\section{Elif YENEROĞLU - Onur KINLI}

Finally, the US was not willing to acquiesce to the right of Denmark to levy such dues because this had the danger of setting a precedent for demanding similar dues by other powers at the Gibraltar, Messina or the Dardanelles. ${ }^{67}$

It was, however, obvious that the matter would be solved within the context of the balance of power in Europe. From the European point of view, it was the US that had a peculiar attitude towards the issue. Setting aside the fact that dynastic ties with Denmark could allow the Russian tsar to take over the Sound dues in the future, the Russian foreign minister Nesselrode for example, did not understand why an old and internationally accepted practice should be questioned, and on what ground could it be claimed that Denmark had no right to dues that were centuries old ${ }^{68}$ Furthermore, for a Russia that is suspicious of any hostile country that might enter the Baltic, the compulsory stop of ships at Elsinore served as a police station. There were even rumors in 1854 that Russia would not allow American ships which did not pay dues to Russian ports ${ }^{69}$ In their ongoing political rivalry with Denmark over the duchies of Schleswig and Holstein, the Prussians were very keen on abolishing the Sound dues. Hessenland's article mentioned above approaches the issue on several dimensions. Hessenland argued that the Sound dues had become part of a system that the Danish government used to obstruct the progress of the Baltic trade. Denmark resisted any reduction on the dues imposed on the river Elbe. Moreover, Hamburg-Berlin and Lubeck Railways were also to pay taxes to Denmark. The passage of Schleswig-Holstein Canal was also subject to similar dues as the Sound dues. The taxes laid on land through various means rather seemed to be an instrument in Denmark's rivalry with Prussia since it was Prussia that was most affected by the restrictions imposed on land trade. Hessenland remarked, Denmark, with her tax gatherers, is master of all the gateways between Northern Europe and the ocean. ${ }^{70}$ Furthermore, Hessenland not only criticized previous actions by Prussia which acquiesced to the right of Denmark to levy dues but accused the other great powers for pursuing their own self-interests rather than putting collective pressure on Denmark for the abolition of the Sound dues once and for all. ${ }^{71}$

The British, on the other hand, were reluctant to burden their Treasury with such an amount, and were finding it hard to make the parliament and the public opinion accept the use of public money for the benefit of a few traders. ${ }^{72}$ The fact that Prussia and France pushed for a general treaty is further proof that the matter was a political rather than a commercial or legal one for the European nations. Last, but not least, the US chose to overlook the impossibility of abolishing the dues for one country and imposing them on the rest. Thus, the issue, regardless of the political complications it engendered, had to be solved within the diplomacy of the Concert of Europe. The manner in which the problem of the Danish Sound was handled by the great powers of Europe also showed that

\footnotetext{
${ }^{67}$ From Marcy to Bedinger, 1855, p. 39.

${ }^{68}$ Ahonen 2005, p. 116.

${ }^{69}$ Ahonen 2005, p. 116.

${ }^{70}$ Hessenland 1855, p. 405.

${ }^{71}$ Hessenland 1855, pp. 409-412.

${ }^{72}$ Ahonen 2005, p. 106.
} 
although the general tendency towards a more liberal regime in international straits was being debated, they made no reference to the principle of freedom of the seas and preferred to settle the question on political grounds. Hence, a process which started with American initiative was resolved without its attendance.

The resolution of the issue between the US and Denmark was through the signing of a new treaty on April, 11, 1857. In essence it is the same with the general treaty, except the article stating that the treaty of 1826 which was abrogated went into effect and became binding between the two states, excepting, of course, article 5. The US was to pay its share without however, uttering any words as to compensation or purchasing the right of free passage. ${ }^{73}$ The fact that the US paid the exact amount of its share that was calculated during the international Congress can actually be considered as acquiescing to the decision of the European Concert without formally yielding to it. Although the US showed that the matter was legal in nature by not joining the Congress, it was still far from imposing its will on other powers for establishing this as a principle of international law. Thus, that principle remained yet to be challenged for future cases, which the US had faced only two decades later.

The American attitude regarding the Sound dues question was criticized by some Americans for two main reasons; first the harsh attitude adopted by the US towards a friendly government in the resolution of the matter was not understood by many, including politicians. The point which was criticized the most in this respect was that the US threatened to terminate the commercial treaty with Denmark, apparently without exhausting all diplomatic means and in the midst of a crisis that directly involved the majority of the great powers of Europe. When the time for the termination had come, however, the powers of Europe were in congress to solve the issue, and the US postponed the termination to wait for the results of the congress that it did not attend, thus putting itself in an embarrassing position by not carrying out the threat of termination.

The second reason was the principle of the freedom of the seas. The criticism directed at this principle by the Americans is a proof that it was not digested in the US either. One critique, from a curious angle defines the step taken by the US on the modern theory of mare liberum a political experiment which all the sacrifices and risks had the danger of falling upon the American commerce because the Sound dues never had any material importance for the US and that Prussia and Britain, not the US will benefit more from the abolition of the dues. ${ }^{74}$ The critique then equates the abolishing of the dues by force and without offering an adequate indemnity as an attack upon the great principle of

\footnotetext{
73 Article 3 reads: In consideration of the foregoing agreements and stipulation on the part of Denmark, whereby the free and unencumbered navigation of American vessels through the Sound and the Belts is forever secured, the United States agree to pay to the Government of Denmark once for all the sum of seven hundred and seventeen thousand, eight hundred and twenty nine Rix dollars, or its equivalent, three hundred and ninety-three thousand and eleven dollars in United States currency, at London on the day when the said Convention shall go into full effect as herein afterwards provided. https://www.loc.gov/law/help/us-treaties/bevans/b-dkust000007-0011.pdf. Accessed November 18, 2019.

${ }^{74}$ McDermott 1855, pp. 2-3.
} 


\section{Elif YENEROĞLU - Onur KINLI}

property, and even calls it international communism or socialism. ${ }^{75}$ One US Senator called the action taken by US as Quixotic, because he found it hard to understand why the US when it had very little at stake compared to other interested parties of Europe, would be the champion of Europe when trying so hard to avoid entanglement in European affairs. ${ }^{76}$ Thus, the principle upon the US founded its arguments had its own critiques at home and the US was still far from posing a challenge to British hegemony over the development of international law.

\section{Turkish/Black Sea Straits:}

Turkish Straits comprise two straits, the Bosporus and Dardanelles which connect the Black Sea and the Mediterranean, and the inland Sea of Marmora that lies in between the two straits. The territorial sea on both shores of the straits overlap, which suits well to the debate in the $19^{\text {th }}$ century as to what degree a coastal state should exercise sovereignty over these waterways. Towards the end of 1860s the US attempted to challenge the status quo of the Turkish Straits again on the principle of freedom of the seas, but compared to the Sound dues question the matter was too complicated to be discussed purely in legal terms. In other words, the status quo in the Turkish Straits was maintained through an uneasy consensus among the great powers of Europe without having regard to the rules of international law.

The Straits question, as it was called, was one of the crucial aspects of a greater issue, the Eastern Question. In its oversimplified form, the question of how the great powers of Europe would share the spoils of the Ottoman Empire in case of its collapse was the central concern of the Eastern Question. The weakness of the Ottoman Empire in fact posed a great threat to the European states system. The possibility of a sudden collapse and without prior agreement over the spoils of the Empire had the potential to drag the great powers into a major war. On the other hand, the strategic, economic and political interests of the great powers over the Ottoman Empire were so irreconcilable and each power was so apprehensive of the other's designs that it was impossible to reach an agreement that would fully satisfy the aspirations of each and every great power at the same time. Furthermore, the diversity and complexity of issues covering the Eastern Question ${ }^{77}$ made the problem more problematic and more prone to conflict. Therefore, most of the time the great powers preferred the survival of the Empire in its weak state rather than having to deal with the dangers of the power vacuum that would be created by its demise.

The Straits question began to develop with the signing of the Treaty of Kuchuk

\footnotetext{
${ }^{75}$ McDermott 1855, p. 35.

${ }^{76}$ Ahonen 2005, p. 116.

77 There is a general agreement among the scholars that the Eastern Question began with the treaty of Kuchuk Kainardji (1774) and ended with the Treaty of Lausanne (1923). A wide range of economic, political and strategic issues of a changing nature fell into the orbit of the Eastern Question. Apart from the Straits, the minorities, concessions, capitulations, territorial integrity of the Empire, and oil towards the end of the $19^{\text {th }}$ century were major topics of interest for the great powers.
} 
Kainardji between Russia and the Ottoman Empire in 1774. With the treaty, Russia was able to settle on the shores of the Black Sea. A natural consequence of Russia's acquisition of an outlet to the Black Sea was the right to navigate its merchant ships through the Straits (Article 11). Until then, the Black Sea being an inland sea, no foreign merchant or war vessels of any nation was allowed to trade in Black Sea ${ }^{78}$ except on seldom occasions and only with firmans granted by the Ottoman Sultan. Following the Russian precedent other European powers acquired the rights of passage through signing treaties with the Ottomans. The Straits remained closed to nations with no treaties and the passage of war vessels remained prohibited and the authority to open the Straits to foreign vessels remained at the Sultan's discretion, which was referred to as "the ancient rule of the Ottoman Empire."

Russian territorial expansion in the Black Sea basin continued in the following decades, making the other great powers of Europe more and more apprehensive of Russian designs over the Straits. The geostrategic location of Russia made it almost imperative for it to acquire the Straits, the keys to their house, as the Russians called them. In the west the Russian territory had two outlets to the sea, one from the Baltic, one from the Black Sea both of which were controlled by other states which made Russia militarily vulnerable and at the mercy of the coastal states for its security. The Baltic Sea remained practically closed during winter which made the Turkish Straits more important, especially as Russian grain production and export flourished during the $18^{\text {th }}$ century. Catherine the Great followed policies to attract more trade for the Russian grain, the control of the Straits became vital for Russian commercial interests as well. However, a chokepoint as important as Straits would not be left at the hands of the Russians, especially by the British who saw any Russian attempt in this regard as a threat to its major lines of communication to India through the Mediterranean Sea. Accordingly, the Straits became a central component of balance of power politics, the very thing that the US wanted to stay out of.

The Straits question, like most other aspects of the Eastern Question, presented a dilemma. As Russia developed its naval strength the major concern was to keep other great powers out of the Black Sea while it could navigate its navy freely in and out of the Straits. The other great powers, especially Britain, desired just the opposite: keep the Russian navy locked in the Black Sea while their navies navigated freely through the Straits. Therefore, any attempt to establish a legal regime for the Straits would never create the conditions which would satisfy the vital interests of all the great powers at the

\footnotetext{
${ }^{78}$ Prior to Kuchuk Kainardji, capitulations that were granted to states like the French, English and the Austrians contained clauses which gave the right to sail their merchant vessels in all the waters of the Ottoman Empire. In practice, however, the Ottomans continued to prohibit the passage of foreign vessels through the Straits. Tukin 1999, pp. 32-35. In the $18^{\text {th }}$ century we see merchant vessels sailing as far as the southern mouth of the Bosporus from where their cargo to the Black Sea was carried on vessels under Ottoman flag. Hurewitz 1962, p. 607. Following the Russo-Ottoman war of 1828-1829, the seventh article of the Adrianople treaty declared that the passage through the Straits was free and open to all the merchant-ships of Powers who are at peace with the Sublime Porte ... upon the same conditions which are stipulated for vessels under the Russian flag.
} 


\section{Elif YENERO $\breve{G} L U-$ Onur KINLI}

same time. This was the initial phase of the question when the passage of war vessels was still at the discretion of the Ottoman Sultan. A brief account of the international agreements that regulated the regime of Turkish Straits would enable us both to understand the Straits question and the development of American policy towards the Straits.

The Muhammed Ali crisis (1831-41) began as a domestic nuisance but rapidly developed into an international crisis posing a serious threat to balance of power in Europe and had far reaching consequences regarding the Straits question. Due to the initial lack of interest from the British government the Ottomans turned on to the Russians for help, which resulted in the signing of the Hunkar Iskelesi Treaty (1833). A defensive alliance was formed between the Ottomans and the Russians while a secret clause attached to the treaty stated that the Straits would be closed to all foreign vessels of war whenever Russia was engaged in a defensive war. Although this was only a slightly altered reiteration of the "ancient rule of Empire" it was alarming enough for the remaining great powers. The alliance was signed for a period of eight years, and when the time came for a renewal the great powers were determined not the let any of them to gain the upper hand over the Straits. The result was the London Straits Convention of $1841 .{ }^{79}$ The Convention recognized freedom of navigation for all merchant ships and prohibited the passage of war vessels, which the great powers were to respect and to conform (Article I) except small ones which paid courtesy visits to Istanbul. Each war vessel destined to pass through the Straits could only do so with a firman from the Sultan (Article II). It was at the Sultan's discretion to open the Straits to the war vessels of the friendly powers if the Ottomans were at war. The Convention had two vital consequences: first, although the closure of the Straits to war vessels was referred to as the "ancient rule of the Empire," implicit in this phrase was the notion that the Sultan could actually open the Straits as he pleased. When this "ancient" rule was codified as a principle of public international law it meant that the Sultan had formally surrendered his right to open the straits at his discretion during peacetime ${ }^{80}$ Second, by declaring that they would respect the principle and abide by it the great powers were pledging themselves to the observation of that principle. Therefore, it was now the collective duty of the great powers to guarantee the principle, the violation of which would represent a challenge not only to the Porte but also to the European balance. It was the first international instrument that

\footnotetext{
${ }^{79}$ Shortly before the Convention of 1841 , the Convention for the Pacification of the Levant was signed between the great powers (excluding the French) and the Ottomans (1840). The convention stipulated the assistance of the signatories to the Ottoman government in case Muhammed Ali refused to submit to the will of the powers on the Egyptian issue. This assistance inevitably included the passage of war vessels of the powers mentioned above. It was expressed clearly that the deployment of navies was an exception and temporary, not a derogation from the ancient rule of the Ottoman Empire, in virtue of which it has at all times been prohibited for ships of war of foreign Powers to enter the Straits of the Dardanelles and of the Bosporus. While the Sultan declared that he would maintain the ancient rule of the Empire the signatories pledged themselves to respect the principle (article IV).

${ }^{80}$ Bederman 1988, p. 6.
} 
directly incorporated a collective organization preserving a legal regime. ${ }^{81}$ Although the convention was signed only between the great powers and the Ottomans, it was the codification of the "ancient rule" and therefore other nations were expected to continue to observe the rule. This actually meant that the Ottomans were not powerful as once they were to impose the ancient rule and the great powers found it convenient to continue with this principle only to avoid further conflicts with each other.

The Crimean War was another crucial milestone in the history of the Straits question as well as the European States System. Following the defeat of Russia by the joint forces of Britain, France, Kingdom of Sardinia and the Ottoman Empire, the Black Sea was demilitarized except for small naval forces for the maintenance of coastal security. Furthermore, no naval arsenals would be built and the existing ones were to be destroyed. The parties gained the right to position two light vessels at the mouth of the Danube to ensure the proper execution of the treaty. As far as the legal regime of the Straits was concerned the status quo did not change. However, the demilitarization of the Black Sea was a major blow to Russia's power and prestige. From then on Russia would seek for an opportunity to get rid of the limitations imposed on it, which also meant that it was now a potential destabilizer of the European States System like France. That opportunity came in 1871 , following German unification. This was also when the US faced the dilemma of taking initiative or going along with the decisions of the great powers. The events of 1871 which led to London Declaration will be dealt with below together with US policy.

\section{The US and Turkish/Black Sea Straits}

As early as $1797^{82}$ the US was interested in signing a commercial treaty with the Ottomans, which would also allow the free passage of American merchant vessels through the Straits, but it was not until 1830 that they were able to do so. Following the signing of the commercial treaty the Americans opened a consulate in Odessa, but trade never reached a satisfactory level except during the Crimean war when American ships were used in the transportation of the British, French, Sardinian and Ottoman armies. ${ }^{83}$

\footnotetext{
${ }^{81}$ Bederman 1988, p. 7.

${ }^{82}$ Kirchner gives 1819 as the earliest date, but we were able to trace these efforts back to 1797 . For a detailed account of the painful process of signing the commercial treaty see, Kinli 2009, pp. 117-130. Kirchner also mentions Emperor Nicholas was reported to have used his personal influence to induce Turkey to allow [the freedom of passage] to American merchants. Kirchner 1975, p. 119. An article published in Hunt's Merchants' Magazine points out to the fact that it [was] not improbable that the Russian government was desirous that such a trade should grow up between Odessa and the United States, for the correspondence alluded to shows that the Russian Embassy at Constantinople aided in opposing the unfriendly influence of the British ambassador, and in securing the ratification of the treaty of May, 1830, by the Sultan's ministers. March 1857, Vol. XXXVI, Number III, p. 282.

${ }^{83}$ Hunt's Merchants' Magazine, March 1857, pp. 284-285. Although the Americans blamed the British for not being able to gain a foothold in the Black Sea, the real reason for the low level of trade was the lack of commodities that would serve as return cargoes both from the Russian and
} 


\section{Elif YENERO $\breve{G} L U-$ Onur KINLI}

Kirchner states that the Black Sea commerce moved as if under a law of its own, mirroring American rather than Russian neglect. ${ }^{84}$ Therefore, the Baltic continued to be the primary route for Russo-American trade.

Compared to the Sound issue, one might question as to why the US posed a challenge to the status quo of the Turkish Straits since with the signing of the commercial treaty the problem of passage through had been solved for American merchant ships. It was, however, not the commercial but the legal status that the US was preparing to challenge. Howard argues that although American commercial interests in the Black Sea did not rank at the top, the rules regulating the passage of war vessels through the Straits did cause some problems for the US and indeed contributed to the development of American policy with regards to passage through international waterways in general. ${ }^{85}$ Thus, the argument was to be founded upon the freedom of the seas ${ }^{86}$ and restrictions on international waterways that connect the high seas.

Article VII of the Treaty of Commerce and Navigation secured the rights of passage through the Straits, but there was no regulation regarding the passage of war vessels, which was not peculiar at least for the Ottoman Porte because no such right was granted to any other nation. Accordingly, the request for the passage of a US war vessels in 1835 was rejected by the Porte upon advice from the Russian Embassy to avoid setting a precedent. ${ }^{87}$ On certain occasions the Ottoman Porte granted permission for the passage US war vessels paying courtesy visits or for other diplomatic purposes, but the vessels were not permitted to sail to the Black Sea ${ }^{88}$ For almost three decades the US did not pursue the matter, even when the Sound dues were abolished which could have set a precedent for US claims for the Turkish Straits. In 1862, a new treaty of commerce and navigation was signed where it stated that the firmans required for merchant vessels of the United States of America, on passing through the Dardanelles and the Bosphorus, shall always be delivered in such manner as to occasion to such vessels the least possible delay (article 16).

In July 1868, the House of Representatives, accepted a resolution without any discussion to urge upon the Government of the Sultan the abolition of all restrictions through the [Straits] ... and to endeavor to procure the perfect freedom of navigation through those Straits to all classes of vessels. ${ }^{89}$ Edward Joy Morris, American minister to Istanbul, was enthusiastic about the resolution and believed that the time had come to abolish all restrictions on war vessels. He justified the initiative on the grounds that the future of the United States is so vast and the enterprise of the American people so great,

Ottoman ports (including Constantinople) in the Black Sea. Hunt's Merchants' Magazine, March 1857 , p. 283.

${ }^{84}$ Kirchner 1975, p. 121.

${ }^{85}$ Howard 1974, p. 4.

${ }^{86}$ Howard (1974) describes this principle as rather vague.

${ }^{87}$ Howard 1974, p. 4.

${ }^{88}$ Howard 1974, p. 6-8.

89 Congressional Globe for the Second Session Fortieth Congress, Part IV, Office of the Congressional Globe, July 6, 1868, p. 3765. 
that our commerce may take quite a large development in this part of the East at no distant period. In this aspect the restrictions and regulations in question seem to deserve consideration. ${ }^{90}$ Furthermore, he argued that the US was not a party to any of the international agreements regulating passage through the Straits and the restrictions were harmful to US commerce and contrary to American-Ottoman treaty of 1862, which Morris himself had negotiated. ${ }^{91}$ Apart from article XVI stated above there is no reference to any regulations regarding the passage of war vessels.

Apparently, Morris' enthusiasm was not shared by the government because apart from instructing Morris to collect more information on the matter no further action was taken. ${ }^{92}$ Three months after the resolution Admiral Farragut visited Istanbul, and his steamer USF Frolic was within the limits provided by the Paris Treaty. His flagship Franklin, however, exceeded those limits and minister Morris applied for an exception to be made for it. The Porte replied that exceptions can only be made for the princes of the blood. Since there was no aristocracy in the US, minister Morris argued that the sovereigns of Europe had treated him with princely honors, and had received him with a distinction rarely granted to other than royal personages. ${ }^{93}$ The permission for the passage of Franklin was granted only after the great powers gave their consent. After the departure of Franklin, the Sublime Porte nevertheless felt the need to reiterate the restrictions imposed by the Paris Treaty and sent a circular to the powers stating that from then on there will be no exception but for vessels of war, which may have on board a sovereign or the chief of an independent state. ${ }^{94}$

For three years there were neither cases that necessitated the bringing up the question of passage of war vessels nor initiatives on the part of the government was to follow the matter as instructed by the House of Representatives. In 1870 the matter came to the attention of the US not because of its own initiative but because of the dramatic shifts in the balance of power in Europe. At the height of the Franco-Prussian war of 1870 Russia invoked the principle of rebus sic stantibus arguing that the changes that took place since the signing of the Paris Treaty had proven to be detrimental to Russia's security ${ }^{95}$ and that the demilitarized status of the Black Sea should end. ${ }^{96}$ They also drew attention to the violation of the treaty by foreign vessels of war. However, the Russians were only offering a partial revision in the treaty, which would put them in an advantageous position because while the Black Sea would be remilitarized, they would

${ }^{90}$ Howard 1974, p. 10.

91 Howard 1964, pp. 217-18.

92 Moore 1906, p. 664.

${ }^{93}$ From E. Joy Morris to William H. Seward, August 24, 1868, FRUS, vol. 2, no. 267, pp. 114-15. http://digital.library.wisc.edu/1711.dl/FRUS.FRUS186869v02, accessed, 10.05.2019.

94 Circular on the prohibition of the passage of the Dardanelles and Bosphorus by foreign vessels of war, Sublime Porte, Ministry of Foreign Affairs, September 28, 1868, FRUS, vol. 2, p. 117. http://digital.library.wisc.edu/1711.dl/FRUS.FRUS186869v02, accessed, 10.05.2019.

95 These were the establishment of a quasi-independent Romania, which in fact could pose no threat to Russian security, and the introduction of ironclad vessels which could in fact pose a threat to naval balance and thus Russia's security. Bederman 1988, p. 10.

96 Herstlet 1875, pp. 1892-97. 


\section{Elif YENEROĞLU - Onur KINLI}

prevent foreign powers from entering it. At a time when Europe was in turmoil Alexander II was sure that none of the great powers would challenge Russia militarily. In fact, the Tripartite Covenant that was signed between Britain, France and Austria did require military action to preserve the Paris Treaty. However, as Bederman states, these powers no longer felt themselves bound to preserve the Paris regime. It was an artificial agreement, created to perpetuate a balance of power that was really untenable in 1856 and utterly irrelevant by $1871 .{ }^{97}$ Furthermore, Austria's apparent lack of interest in the crisis coupled with the defeat of France to Prussia followed by internal turmoil, meant that the burden would fall on Britain alone. Under these circumstances the only facesaving way to solve the problem was to convene another conference of great powers. Consequently, it was not just Russia that was challenging the Paris Treaty, but it was also the guarantors by not taking any action to preserve it.

Apart from remilitarizing the Black Sea the London Conference of 1871 procured no radical changes in the regime of the Straits. The Ottomans attempted to return to the "ancient rule of the Empire," that is, regaining the Sultan's authority to open the Straits at his discretion, but only a vague impression was adopted instead. The principle of closing the Straits as it was established in the separate Convention in 1856 was retained, but the Sultan was given the power to open the Straits in time of Peace to the Vessels of War of friendly and allied Powers ... in order to secure the execution of the stipulations of the Treaty of Paris. ${ }^{98}$

It was under these circumstances that the question of the Straits fell into the agenda of the US. Minister Morris was closely following the developments and as early as September, nearly a month before the Russian note to the great powers, he informed Washington about the possible Russian initiative on the revision of the Paris Treaty. ${ }^{99}$ The US was not a party to any of treaties governing rules of passage through the Straits and therefore he believed that it had every right to complain about the restrictions. Nevertheless, a minor scandal shows us that the government was cautious not to get dragged into the balance of power politics even when the matter was of vital importance. During the crisis President Grant sent a letter to the Russian Emperor congratulating him on the denunciation of the Black Sea clauses of the Paris Treaty. Obviously, President Grant was not well informed on the matter because Russia was in favor of lifting only a portion of the restrictions that would make it advantageous over other powers. Furthermore, it was unconventional for US Presidents to send letters to other heads of state except letters of ceremony.

Upon this minor scandal Morris' successor Mac Veagh deemed it necessary to send a detailed report explaining the geography of the Straits, and a brief history of the

\footnotetext{
${ }^{97}$ Bederman 1988, p. 13.

${ }^{98}$ Article II of the Convention Between Great Britain, Austria, France, Germany (Prussia), Italy, Russia, and the Ottoman Empire, for the Revision of Certain Stipulations of the Treaty of March 30, 1856 (Signed at London, March 13, 1871) in Herstlet vol. III 1875, p. 1921.

99 From Hamilton Fish to Wayne Mac Veagh, January 5, 1871, FRUS 1870-71, no. 15, p. 890. http://digital.library.wisc.edu/1711.dl/ FRUS.FRUS187071, accessed 10.05.2019
} 
Straits question accompanied by major treaties, ${ }^{100}$ followed by another extensive dispatch discussing the validity of US arguments. Unlike Morris, Mac Veagh presented a much more conservative and cautious view of the matter. He drew attention to several aspects with regards to the previous policy of the US on the observance of the rule of prohibition of the passage of war vessels. First, he made clear that although there were a number of treaties that prohibited the passage of war vessels through the Straits, this in fact rested upon the immemorial usage ... explicitly recognized by the authoritative treatise of Wheaton, ${ }^{101}$ sanctioned by the recognition and respect of all nations at peace with the Porte ... and whose validity and prosperity are not known to have been ever seriously questioned. ${ }^{102}$ Secondly, Mac Veagh argued that the US legation in Istanbul during the past decades had applied for firmans for the passage of its war vessels for certain diplomatic missions, and never actually expressed any form of dissatisfaction or challenged the validity of the ancient rule. As mentioned above, when the Porte reminded the powers in 1868 that there would be no exceptions to the ancient rule the US did not object either. On the contrary, the exception granted by the Porte to the Franklin was praised by Morris because no such exception was granted to any other great power, which was in fact another demonstration of US acquiescence. Finally, Mac Veagh drew attention to the 1830 treaty of commerce, by which the diplomatic relations between the US and the Ottoman Empire started. He argued that the treaty secured for our vessels of commerce the right of passing these straits; and thus excluded the idea that we possessed the same right for our ships of war. In the long interval we have uniformly recognized, in all the modes known to diplomatic intercourse, the continued existence of the distinction. ${ }^{103}$ Therefore, unlike Morris, Mac Veagh did not think that the prohibition of the passage of war vessels was against the treaty of 1862 .

The views that Mac Veagh presented in his dispatch were shared by the Department of State as well. Secretary of State Fish finalized the debate by stating that the US government was not disposed to prematurely raise any question to disturb the existing control which Turkey claims over the straits. ${ }^{104}$ However, while the US did not deny the existence of usage it also made clear that it was important to avoid recognizing it as a right under the law of nations. ${ }^{105}$ Therefore, the US adopted a middle course in the matter, it neither gave in nor did it take vigorous action to challenge the status quo.

${ }^{100}$ From Wayne Mac Veagh to Hamilton Fish, January 24, 1871, FRUS 1871-72, no. 23, pp. 892-96.

${ }^{101}$ Henry Wheaton (1785-1848) was one of the most prominent and highly praised international jurists of the US. He was also a diplomat, the first US chargé d'affaires to Denmark. He was a prolific writer of international law and its history. Thus, he was considered as an authoritative figure on international law by the US government.

102 From Wayne Mac Veagh to Hamilton Fish, March 27, 1871, FRUS 1870-71, p. 898, http://digital.library.wisc.edu/1711.dl/FRUS.FRUS187071, accessed 10.05.2019.

103 From Wayne Mac Veagh to Hamilton Fish, March 27, 1871, FRUS 1870-71, p. 898, http://digital.library.wisc.edu/1711.dl/FRUS.FRUS187071, accessed 10.05.2019.

104 From Hamilton Fish to Wayne Mac Veagh, May 5, 1871, p. 902, FRUS 1871-72, http://digital.library.wisc.edu/1711.dl/FRUS.FRUS187071, accessed 10.05.2019.

105 From Hamilton Fish to Wayne Mac Veagh, May 5, 1871, p. 902, FRUS 1871-72, http://digital.library.wisc.edu/1711.dl/FRUS.FRUS187071, accessed 10.05.2019. 


\section{Elif YENEROĞLU - Onur KINLI}

\section{Conclusion}

The principle of the freedom of the seas goes back to almost time immemorial. However, it became a major debate in the later Middle Ages when maritime commerce expanded to cover those parts of the world which were not included in the established trade routes hitherto. It was the challenge of the rising maritime powers against Spain and Portugal's claims to large tracts of the oceans as their own domains that brought about this debate. The driving force behind the principle of freedom of the seas was not altruism or common good but rather the competition between maritime powers to establish hegemony over commerce. Therefore, the principle cannot be understood as a purely technical question but as a political one not devoid of hegemonic rivalries. As Benno Teschke quotes Grewe: the liberty of the sea did not mean its depoliticization, however, but its division among the leading commercial maritime powers. While the mid-19 $9^{\text {th }}$ century 'open door' doctrine, which enshrined the principle of equal opportunity in trade, was predicated on capitalist free trade, mare liberum practices remained tied to the system of competitive national mercantilism. ${ }^{106}$

It is within this framework that we should evaluate US policy regarding the cases discussed above. As a latecomer to the international system the principle of freedom of the seas had been a central element in US foreign policy. The vigorous pursuance of this principle meant ensuring the protection of US commercial interests. Lint goes as far as to assert that commercial and foreign policy were synonymous for the Americans. ${ }^{107}$ The treaty plan $^{108}$ that was adopted in 1776 established a direct link between freedom of the seas and neutral trade which the European states were not ready to accept. The link between this principle and neutrality is a unique one, given the fact that as a newly independent state the Americans were able to create a niche for their commercial transactions by strictly adhering to neutrality during the Napoleonic wars. Therefore, it is no surprise that the first wars that the US engaged in were in defense of this principle. ${ }^{109}$ The fact that American ships were frequently stopped, searched and their goods confiscated created strong resentment and was instrumental in reinforcing this link. Therefore, it was the consistent policy of the US to persuade other nations to accept the principle of free ships free goods. ${ }^{110}$ The consistent advocation of the principle of free ships free goods did not bring about a change in the position of Europeans until when their interests suited to do so. The contradictory practices of the British and the French regarding neutral trade during the Crimean War necessitated an arrangement in this regard which culminated in the Maritime Declaration of Paris (1856). The US failed to adhere to the declaration because the arrangement suited to the interests of the European powers,

\footnotetext{
106 Teschke 2003, p. 201.

${ }^{107}$ Lint 1977, p. 21.

108 Treaty plan is also called the Model Treaty. It is a set of principles that the US would pursue when signing commercial treaties with other states.

${ }^{109}$ The Quasi-war with France, the Barbary Wars, and the War of 1812 with Britain.

110 The principle that advocates enemy goods on a neutral ship should be exempt from confiscation except for contraband.
} 
not that of the US.

When evaluating the cases above we should also take into consideration the impact of Monroe Doctrine in US foreign policy, which was, and is still, incorrectly interpreted as isolationism. ${ }^{111}$ It would be more appropriate to say that the Monroe Doctrine was rather non-interventionist than isolationist. Although European affairs were of much importance to the US it paid great attention to not to get involved in the intricate balance of power politics and avoided political engagements of any sort.

As far as the Sound dues were concerned the US was able to play a leading role because there was a tendency in favor of changing the existing status quo. The principle had already been challenged by the British merchants leading to the agreement of 1841 . Prussia, whose land trade was also hindered by heavy tolls and taxes heavily criticized Denmark. The toll taken by the Danes merely for passage was rather an antiquated practice, a residue of the feudal mentality which did not fit in a modern world. Furthermore, the issue did not pose an imminent threat to the general balance of power in Europe like that of the Turkish Straits. The only great power that could pose a challenge to the abolition of the dues was Russia, which was in no position to do so given its weakness demonstrated in its defeat in the Crimean war. Therefore, the US was able to take a broad step and announce the nonrenewal of its commercial treaty with Denmark. The reason why the great powers were compelled to take up the question in their agendas at a time when the Crimean was in its full swing lay in the system of bilateral treaties. The rates of the dues were determined by bilateral treaties which created a privileged and non-privileged status. Within the privileged status it also created an interconnectedness through the most favored nation clauses embedded in each treaty. By not renewing the treaty the US made it clear that it would not be lowered to the status of a non-privileged nation but would simply not pay the dues. Therefore, if the US could get away with the dues by simply not renewing the treaty the whole system would collapse, and Denmark was not in a powerful position to persuade the US for the continuation of the commercial treaty. Although the US played the major role in the abolition of the Sound dues, in line with its traditional policy it did not become a part of the general treaty but preferred to sign a separate treaty with Denmark.

The case of the Turkish Straits posed a greater challenge for the US and threatened to drag it into European politics, which the US wished to remain detached from. The rules governing passage were determined by multilateral treaties. True, the treaties were signed by only a handful of Europeans nations, but these nations were the great powers of Europe which had a direct interest in the preservation of the status quo in the Straits and lesser nations were expected to follow the rules. Therefore, any unilateral attempt aimed at changing the existing status quo would be met with harsh criticism and the powers would probably take necessary measures including armed ones to reinstate the status quo. Such a challenge by the US would mean that it would find itself in a position which it wished to avoid: entanglement in European affairs. Therefore, it was more appropriate to follow a middle course rather than going forward and taking the lead like it did in the Danish case. While not regarding it as an established principle of international law it did not deny

${ }^{111}$ See Dowty 1971, pp. 5-18. 


\section{Elif YENEROĞLU - Onur KINLI}

the existence of usage.

The common element in these cases as advocated by the US, that is, the principle of freedom of the seas produced different results for the US. This is also a reflection of US pragmatism. It is also an indication of the fact that international law is not exempt from hegemonic relations between nations, and that the US would have to wait for a century to be a major player that will have a more assertive role in the development of rules of international law. 
The United States and International Straits: Two Cases from the $19^{\text {th }}$ Century

\section{BIBLIOGRAPHY}

\section{a. Archival Sources}

Foreign Relations of the United States, Office of the Historian

From E. Joy Morris to William H. Seward, August 24, 1868, FRUS, vol. 2, no. 267, pp. 114-15. http://digital.library.wisc.edu/1711.dl/FRUS.FRUS186869v02, accessed, 10.05.2019.

Circular on the prohibition of the passage of the Dardanelles and Bosphorus by foreign vessels of war, Sublime Porte, Ministry of Foreign Affairs, September 28, 1868, FRUS, vol. 2, p. 117. http://digital.library.wisc.edu/1711.dl/FRUS.FRUS186869v02, accessed, 10.05.2019

From Hamilton Fish to Wayne Mac Veagh, January 5, 1871, FRUS 1870-71, no. 15, p. 890. http://digital.library.wisc.edu/1711.dl/FRUS.FRUS187071, accessed 10.05.2019

From Wayne Mac Veagh to Hamilton Fish, January 24, 1871, FRUS 1871-72, no. 23, pp. 892-96

From Wayne Mac Veagh to Hamilton Fish, March 27, 1871, FRUS 1870-71, p. 898, http://digital.library.wisc.edu/1711.dl/FRUS.FRUS187071, accessed 10.05.2019

From Hamilton Fish to Wayne Mac Veagh, May 5, 1871, p. 902, FRUS 1871-72, http://digital.library.wisc.edu/1711.dl/FRUS.FRUS187071, accessed 10.05.2019.

Other archival material

Hansard's Parliamentary Debates, vol. LVII, 1841.

\section{b. Books and Articles}

Second Annual Message of Franklin Pierce, December 03, 1854, https://www.presidency.ucsb.edu/documents/second-annualmessage-8 Accessed November 18, 2019.

"Sound Dues-Germanic Powers", Department of State, 1841, published in Hazard's United States Commercial and Statistical Register, vol. IV, no. 25, 1841, pp. 397-398.

"The Claims of the Citizens of the United States on Denmark Examined" The North American Review, vol. XXII (new series vol. XIII), 1826 (Boston), p. 458-59.

Ahonen 2005

Kalevi Ahonen, From Sugar Triangle to Cotton Triangle: Trade and Shipping Between America and Baltic Russia, 1783-1860, Unpublished $\mathrm{PhD}$ Thesis, University of Jyväskylä.

Alexandersson 1982 Gunnar Alexandersson, International Straits of the World: The Baltic Straits, The Hague/Boston/London, Martinus Nijhoff Publishers.

Bederman 1988 David J. Bederman, “The 1871 London Declaration, Rebus Sic Stantibus and a Primitivist View of the Law of Nations", American Journal of International Law, Vol. 82, No. 1, p. 1-40. 


\section{Elif YENEROĞLU - Onur KINLI}

Bellamy 1997

M. Bellamy, Danish Naval Administration and Shipbuilding in the Reign of Christian IV (1596-1648), University of Glasgow, Department of Modern History, unpublished PhD thesis.

Burke and DeLeo 1983 Karin M. Burke and Deborah A. DeLeo, "Innocent Passage and Transit Passage in the United Nations Convention on the Law of the Sea" Yale Journal of International Law, vol. 9, issue 2, (The Yale Journal of World Public Order), pp. 389-408.

Caminos and Cogliati-Bantz 2014

Hugo Caminos - Vincent P. Cogliati-Bantz, The Legal Regime of Straits: Contemporary Challenges and Solutions, Cambridge University Press, Cambridge.

Cecil and Forster 1929 "The Freedom of the Seas," Journal of the Royal Institute of International Affairs, Vol. 8, No. 2, pp. 89-116.

Dowty 1971

Alan Dowty, The Limits of American Isolation: The United States and the Crimean War, New York University Press.

Etting 2004

Vivian Etting, Queen Margrethe I, 1453-1412, and the Founding of the Nordic Union, Brill Academic Publishers, Leiden.

Glete 2002 Jan Glete, Warfare at Sea, 1500-1650: Maritime Conflicts and the Transformation of Europe, Routledge.

Hays 1918 Arthur Garfield Hays, "What is Meant By the Freedom of the Seas," The American Journal of International Law, Vol. 12, No. 2, pp. 283-290.

Herstlet 1875 Edward Herstlet, The Map of Europe By Treaty; Showing the Various Political and Territorial Changes Which Have Taken Place Since the General Peace of 1814 with Numerous Maps and Notes, vol. III, Butterworths.

Hessenland 1855 F. Hessenland, The Sound Dues of Denmark and Their Relations with the Commerce of the World, Hunt's Merchants' Magazine and Commercial Review.

Hirst 1918 F. W. Hirst, "What the Americans Mean by Freedom of the Seas," Transactions of the Grotius Society, Vol. Problems of the War, Papers Read Before the Society in the Year 1918, pp. 2634.

Howard 1964 Harry N. Howard, "President Lincoln's Minister Resident to the Sublime Porte: Edward Joy Morris (1861-1870)" Balkan Studies, Vol. 5, No. 2, pp. 205-220.

Howard 1974 Harry N. Howard, Turkey, The Straits and U.S. Policy, Johns Hopkins University Press, 1974.

Jacob 1921 Soren Jacob Marius Peterson Fogdall, History of DanishAmerican Diplomacy, 1776-1920, Unpublished PhD Thesis, State University of Iowa. 
Kınlı 2009

Kirchner 1975

Lint 1977

Lockhart 2007

Martín 2010

McDermott 1855

Menefee 1996

Mohd Rusli 2012

Moore 1906

Moore 1908

Richardson 1897

Somers 2002

Teschke 2003

Tucker 1855

Tukin 1999

Wheaton 1842
Onur Kınlı, 19. Yüzyılda Amerika Birleșik Devletleri'nin İzmir'deki Konsolosluk Faaliyetleri, Ege University, Institute of Social Sciences, Unpublished PhD Thesis, 2009

Walther Kirchner, Studies in Russian-American Commerce, 1820-1860, E. J. Brill Publications, Leiden.

Gregg L. Lint, "The American Revolution and the Law of Nations, 1776-1789", Diplomatic History, Vol. 1, No. 1, p. 20-34. Paul Douglas Lockhart, Denmark 1513-1660: The Rise and Decline of a Renaissance Monarchy, Oxford University Press.

Ana G. López Martín, International Straits: Concept, Classification and Rules of Passage, Springer Publications.

Hugh Farrar McDermott, Letters on the Sound Dues, I-VIII, G.

B. Teubner, Printer.

Samuel Pyeatt Menefee, "The Sound Dues and Access to the Baltic Sea" in Renate Platzöder and Philomène Verlaan (Eds.), The Baltic Sea: New Developments in National Policies and International Cooperation, pp. 101-132, Martinus Nijhoff Pub. Mohd Hazmi bin Mohd Rusli, "A Historical Overview on the Legal Status of Straits Used for International Navigation under International Law" AALCO Journal of International Law, Vol. 1, Issue 2, pp. 111-131.

John Bassett Moore, A Digest of International Law, vol. 1, Government Printing Office.

John Bassett Moore (ed.), The Works of James Buchanan, Comprising his Speeches, State Papers, and Private Correspondence, Volume VIII, 1841-1844, J. B. Lippincott Co. James Richardson, A Compilation of the Messages and Papers of the Presidents, 1789-1897, Washington, Government Printing Office.

Eduard Somers. "The Legal Regime of the Danish Straits", in The Straits Used for International Navigation. Ed. Bayram Öztürk \& Reşat Özkan, Türk Deniz Araştırmaları Vakfı.

Benno Teschke, The Myth of 1648: Class, Geopolitics and the Making of Modern International Relations, Verso Books.

From Marcy to Bedinger, November 3, 1855, in Message from the President to the Two Houses of Congress at the Commencement of the First Session of the $34^{\text {th }}$ Congress, part I, Printed by Beverly Tucker.

Cemal Tukin, Boğazlar Meselesi, İstanbul, Pan Yayıncılık.

Henry Wheaton, History of the Law of Nations in Europe and America form the Earliest Times to the Treaty of Washington. 


\section{Elif YENEROĞLU - Onur KINLI}

Woolsey 1860

Theodore D. Woolsey, Introduction to the Study of International Law, Designed as an Aid in Teaching, and in Historical Studies, James Munroe and Company. 